ReView Article

\title{
The turfgrass in landscape and landscaping
}

\author{
Regina Maria Monteiro de Castilho ${ }^{1 *}$ (D), Rodrigo Castilho Freitas ${ }^{1}$ (D), Patrick Luan Ferreira dos Santos $^{2}$ \\ ${ }^{1}$ Universidade Estadual Paulista (UNESP), Faculdade de Engenharia de Ilha Solteira, Departamento de Fitotecnia, \\ Tecnologia de Alimentos e Sócio Economia, Ilha Solteira-SP, Brazil. \\ ${ }^{2}$ Universidade Estadual Paulista (UNESP), Faculdade de Ciências Agronômicas, \\ Departamento de Ciência Florestal, Solos e Ambiente, Botucatu-SP, Brazil.
}

\begin{abstract}
Turfgrasses have become an essential element in the world landscape, due to their aesthetic, environmental and agricultural values. Since prehistory, specifically in the age of dinosaurs, grass pollens have been reported by historians, as well as African tribes have used grass species around their villages for hunting and defending enemies. Medieval castles were surrounded with grass to better visualize the horizon of the fortress and the lookout of those who approached it. Over the years, seeds were disseminated to various parts of the world, and the lawn began to be reported in books on botany, and its use in gardens began to gain notoriety. Thus, grass species became part of the population's daily life, from the Renaissance to the contemporary-modern period, and make up elements of the garden landscape (residential and private) cemeteries, parks, sports fields, roadside, and more recently, on green roofs. In Brazil, with the enhancement of landscaping and the arrival of several types of turfgrasses, the lawn has become a requirement in the construction of a garden. Currently in the Brazilian market, there are thirteen registered different species of turf, which have characteristics and particularities for their use in the constitution of the landscape and landscaping.
\end{abstract}

Keywords: grass, landscaping composition, lawn, lawn history, turf.

\section{O gramado na paisagem e no paisagismo}

Resumo

Os gramados se tornaram um elemento essencial na paisagem mundial, devido aos seus valores estéticos, ambientais e agrícolas. Desde a pré-história, especificamente na era dos dinossauros, pólens de gramíneas já foram relatados por historiadores, bem como tribos africanas já utilizavam espécies de gramas ao redor de suas aldeias para caça e defesa contra inimigos. Os castelos medievais eram cercados com grama para melhor visualizar o horizonte da fortaleza e vigia de quem se aproximava. Com o passar dos anos, sementes foram sendo disseminadas por várias partes do mundo, e o gramado começou a ser relatado em livros de botânica, e seu uso em jardins começou a ganhar notoriedade. Assim, espécies de gramas passaram a fazer parte do cotidiano da população, desde o período renascentista até o contemporâneo-moderno, e compõem elementos da paisagem de jardins (residenciais e privados), cemitérios, parques, campos esportivos, margens de rodovias e mais recentemente em telhados verdes. No Brasil, com a valorização do paisagismo e a chegada de várias espécies de gramas, o gramado se tornou um quesito na construção da paisagem. Atualmente, o mercado brasileiro conta com treze diferentes espécies de gramas registradas, que apresentam características e particularidades para seu uso na constituição da paisagem e do paisagismo.

Palavras-chave: composição paisagística, grama, gramínea, história do gramado, tapete de grama.

\section{Introduction}

Landscape refers to an association between the place and its inhabitants, being also defined as "formatting the land, implying an association of physical and cultural forms" (Holzer, 1999).

On the other hand, landscaping consists of the art of creating a specific space (Paiva, 2008), involving environmental, functional, aesthetic value and harmony with the characteristics of the place. Thus, it must have a social function of "providing the population with community relations or coexistence", which are favored by the existence of public parks and squares (Bovo and Amorim, 2012).

In the USA, according to Urmy (2019), there is no landscape as iconic as the lawns, which had great

*Corresponding author: regina.castilho@unesp.br 
importance in the development of modern urbanization. Studies on "grass" are intertwined between the areas of Agronomy, Biology, Architecture, Ecology and sports.

Urban lawns constitute, according to Ignatieva et al. (2020), in the most common part of open spaces and green infrastructure in a city, and provide services to the ecosystem (and also the disservices), in addition to different approaches in the biophysical, social, planning and design aspects, including understanding and valuation of that vegetation.

\section{The grass and the turfgrass in history, landscape, and landscaping}

\section{Prehistory}

The oldest specimens of grasses was registered in 100 million years ago (Poinar et al., 2015), therefore known from a geological period when dinosaurs dominated the planet. Prior to this dating, the oldest one was 70 million years ago, at the end of the "era of dinosaurs" (Prasad et al., 2005), both of which were based on food residues from Sauropoda (long-necked dinosaurs). The origin of the Poaceae family is indicated from molecular data at least 55 million years ago, having occurred in the extinct continent Gondwana
(Bouchenal-Khelladi et al., 2010). The first records of grass pollen were from the Paleocene period, in South America and Africa, between 60 and 55 million years ago. This date is after the main extinction events that ended the dinosaur era and the Cretaceous period (Kellogg, 2001).

\section{Middle Ages}

One of the initial reports of grass use by men occurs in the middle of the $10^{\text {th }}$ century, by African tribes, where this vegetation, being herbaceous and in small size, served a dual purpose. They allowed residents and hunters to see the danger approaching from afar (animal or enemy tribe) as well as served as a hideout for hunters, when in pursuit of prey (Haber, 2004). In the medieval period, the first description of sodding (which comes from the word sod, "turf carpet") appears in the 1159 Japanese book "Aatu-tei-kail" or "Sakuteiki" (Bread et al., 2014). This was the first text on Japanese garden planning, in which mentions of the turfgrass appear as the focus of the garden (Takei and Keane, 2011). In medieval castles in Europe, the surrounding grass was kept low (Figures 1 and 2), as a strategy for guards to have an unobstructed view of approaching visitors (Hejcman et al., 2013).

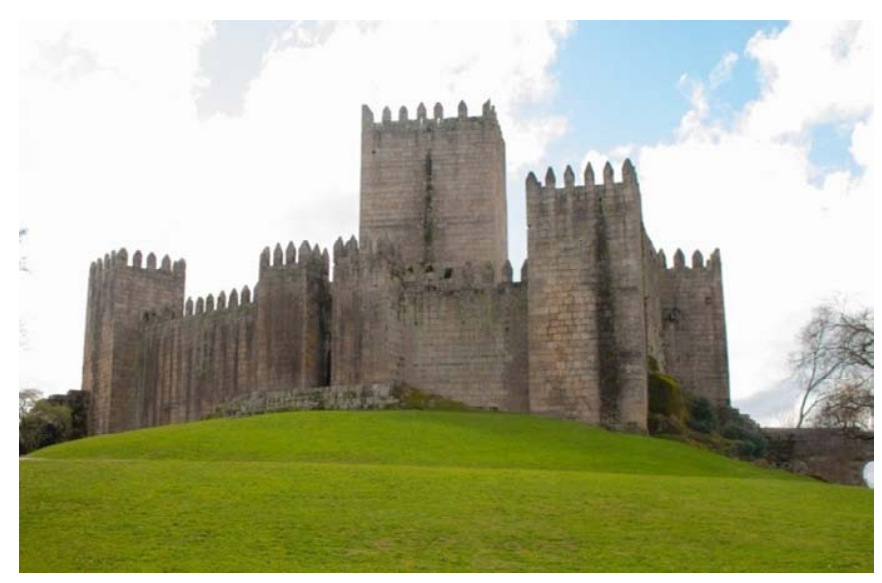

Figure 1. Guimarães Castle - Portugal, dating from the 9th century. Source: Pedaços de nós (2017).

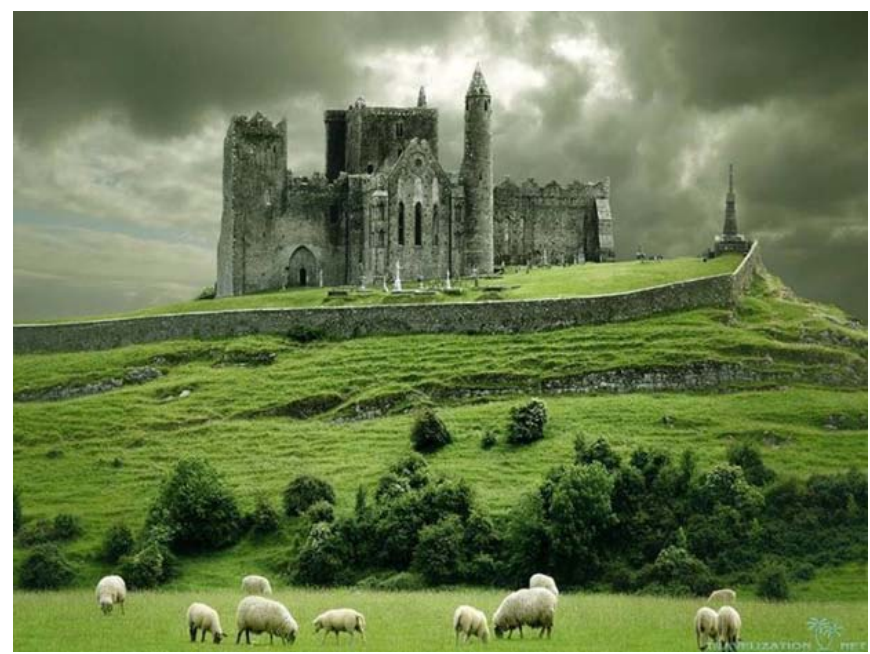

Figure 2. Cashel Castle/Ireland, dated 1134. Source: Pikabu (2018). 
According to Beard et al. (2014), in the $12^{\text {th }}$ century, "perennial and low-growing grasses were regularly defoliated by grazing animals or by hand sickles". The same author also mentions that the English literature of the end of the $12^{\text {th }}$ century and beginning of the $13^{\text {th }}$ century already showed the sportive use of turfgrass (bowling courts, which would be precursors to the tennis, croquet and golf courts). In the second half of the $13^{\text {th }}$ century (around 1260), Alberto Magno (1196-1280), theologian, philosopher, astronomer and scientist, wrote a compendium of Botany ("De vegetabilis et plantis libri septem" - Seven books on vegetables and plants ) (Figure 3); the first five books are theoretical, while the last two are of practical application, in which plants and herbs were listed in alphabetical order, and species of grass and their use in lawns have been mentioned (Neves, 2017).

\section{Renaissance}

Beard and Green (1994) report that during the Renaissance many paintings showed private ornamental lawns and also in public parks. Thus, the turfgrass was portrayed, in 1503, by Albrecht Dürer, in a work entitled "Large Piece of Turf" (Figure 4), and by Giusto Utens, in 1602, who dedicated one of his best "telescopes" to Villa di Pratolino, in which depicts a wide, grassy avenue (Figure 5) (Tomassi and Hirschauer, 2020).
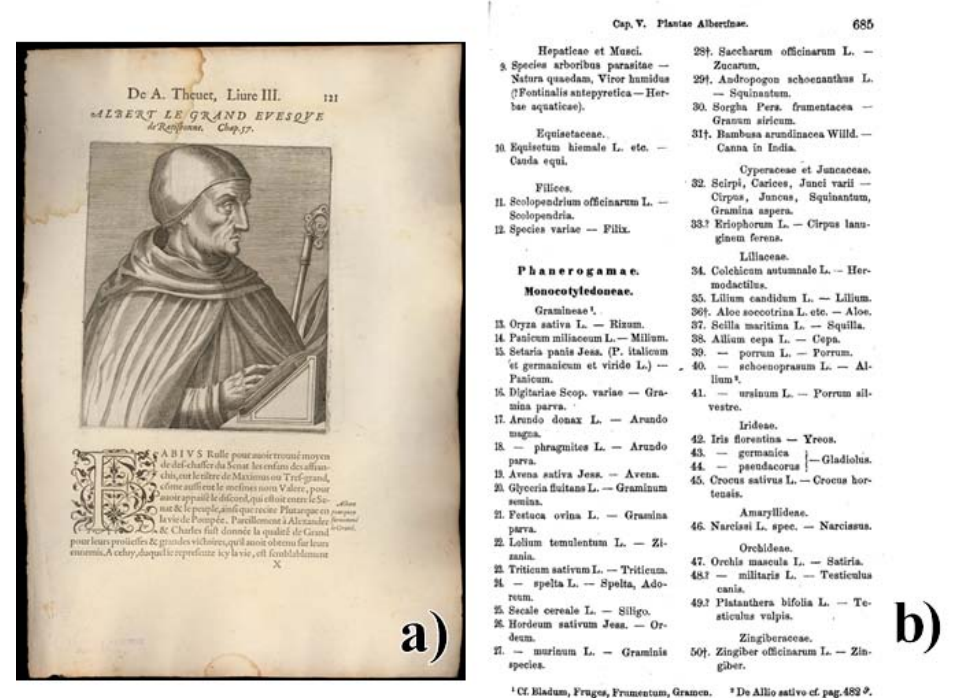

Figure 3. a) Alberto Magno (1196 - 1280); b) Book: "De vegetabilis et plantis libri septem", page 685, grass in items 21 (Festuca ovina) and 22 (Lolium temulentum). Source: a) Iconographie chrétienne (2012), b) Albertus Magnus (2020).

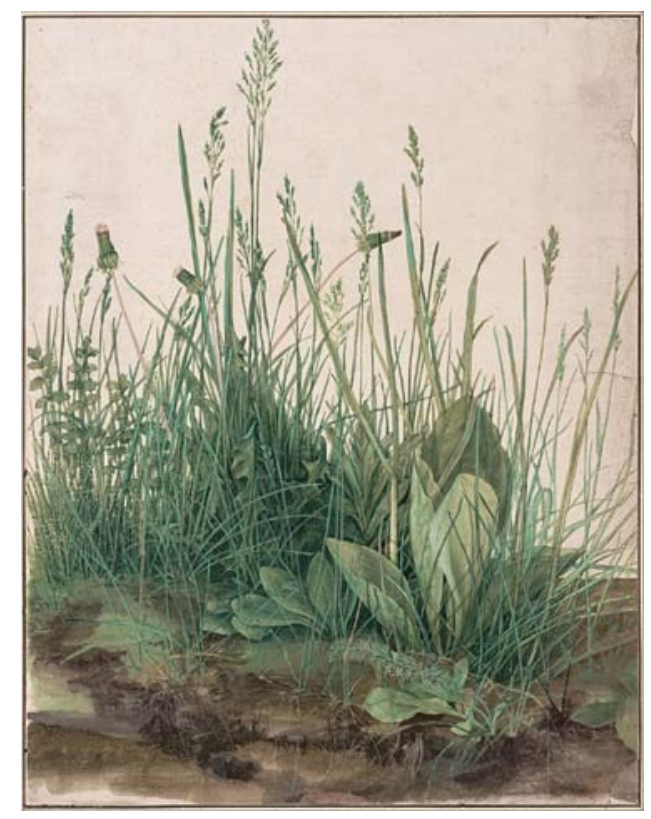

Figure 4. The Large Piece of Turf (1503), Albrecht Dürer. Source: Arts and culture (2020) 


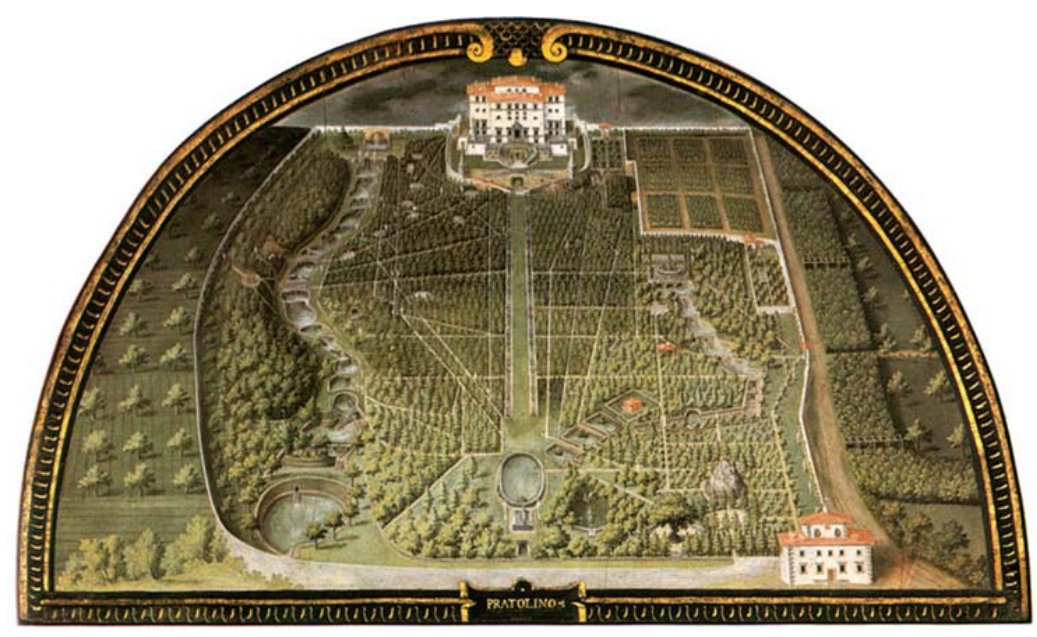

Figure 5. Villa di Pratolino (1602), Giusto Utens. Source: Gardens before (2018)

During this period, a type of football was played on turfgrass in public spaces, being common in most cities and villages in Great Britain, Germany, France, Holland and Austria (Kopec, 2015). In 1665, in Europe, recommendations were published on preparing the beds, selecting grass species (Agrostis and Festuca), harvesting and transplanting to golf courses, with pruning (cutting) being done naturally by sheep (Kopec,
2015). The striking presence of lawns in landscaping during the Renaissance appears clearly in France, in the gardens of Versailles (1624-1688). Designed by André Le Nôtre, shows a symmetrical design, with the great tapis vert (green carpet) with an aesthetic function ( Figure 6), valuing perspective and the feeling of grandeur (Olin, 2017), so that the lawn has become a status symbol.

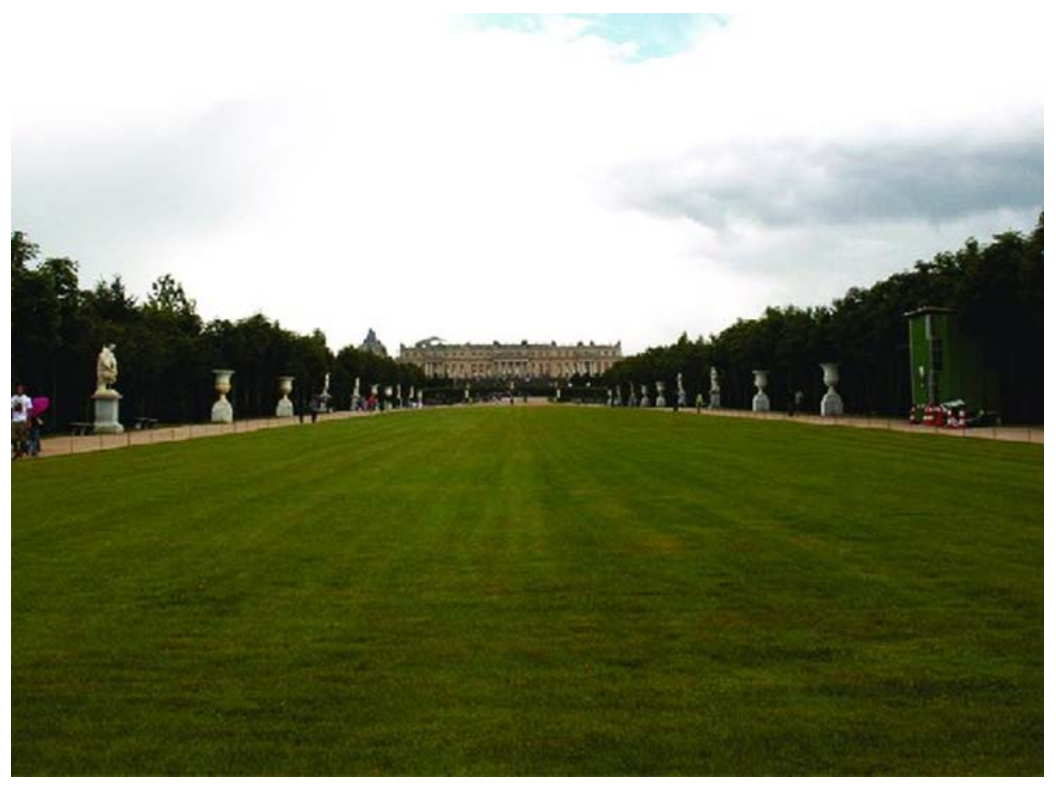

Figure 6. 'Tapis vert' de Versailles/France. Source: Yang et al. (2019).

In England, the trend has tended towards more open landscapes, with fewer fences; the democratic liberalism of the English led to the rejection of despotic French governments and, thus, Renaissance gardens. The gardens began to imitate natural landscapes and consisted of large lawns and the incorporation of lakes and rivers with a natural layout (Liu, 2008; East, 2020); among these are those designed by William Kent (1685 - 1748) (Figure 7) and William Chambers (1723-1796) (Figure 8). 


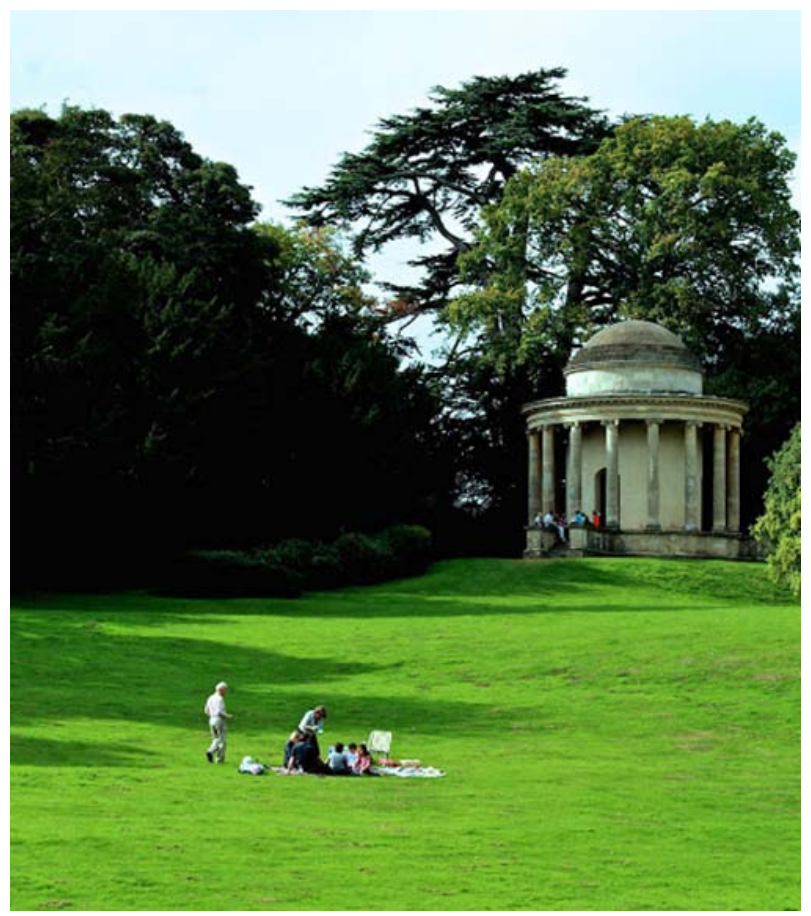

Figure 7. Garden of the Temple of Virtue in Stowe/Buckinghamshire- England, designed by Wilian Kent (1737). Source: Linglung (2016)

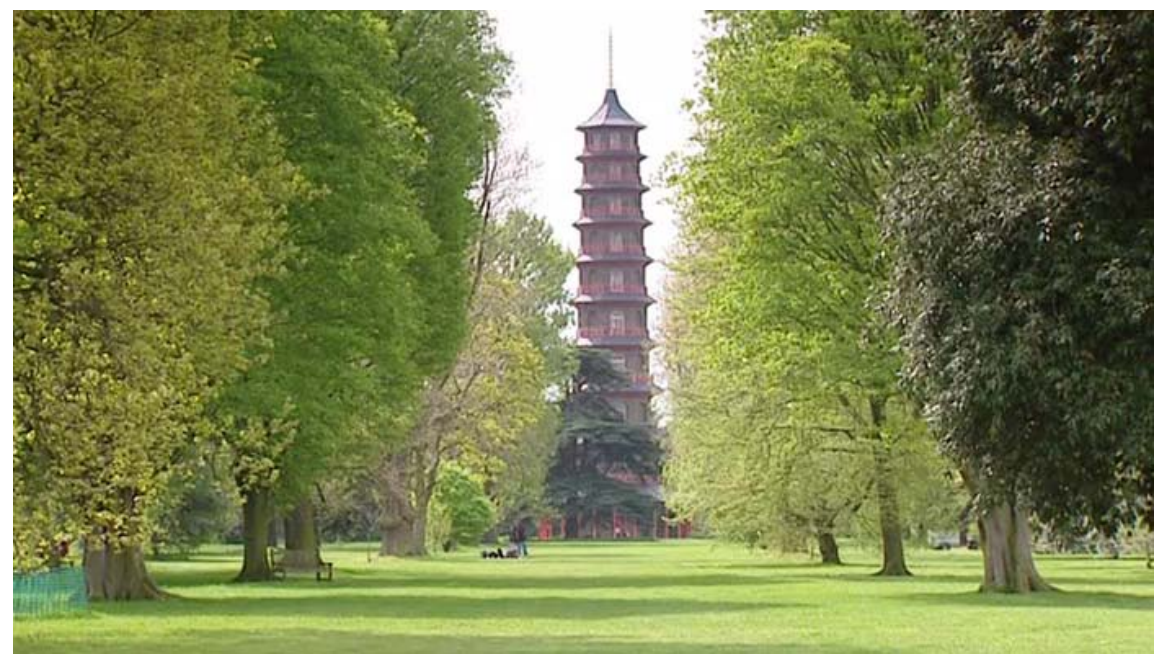

Figure 8. Garden in Kew Gardens/London - England, next to the Chinese pagoda (1761), with a design by William Chambers. Source: Frame pool (2020)

In the $19^{\text {th }}$ century, Napoleon III commissioned JeanCharles Alphand (1817-1891) to urbanize the "square" Batignolles (Paris) (Figure 9), which opened in 1879, with an artificial lake, tortuous paths and extensive lawns (Stewart, 2012 ), thus giving rise to the eclectic style (Anglo-French garden). 


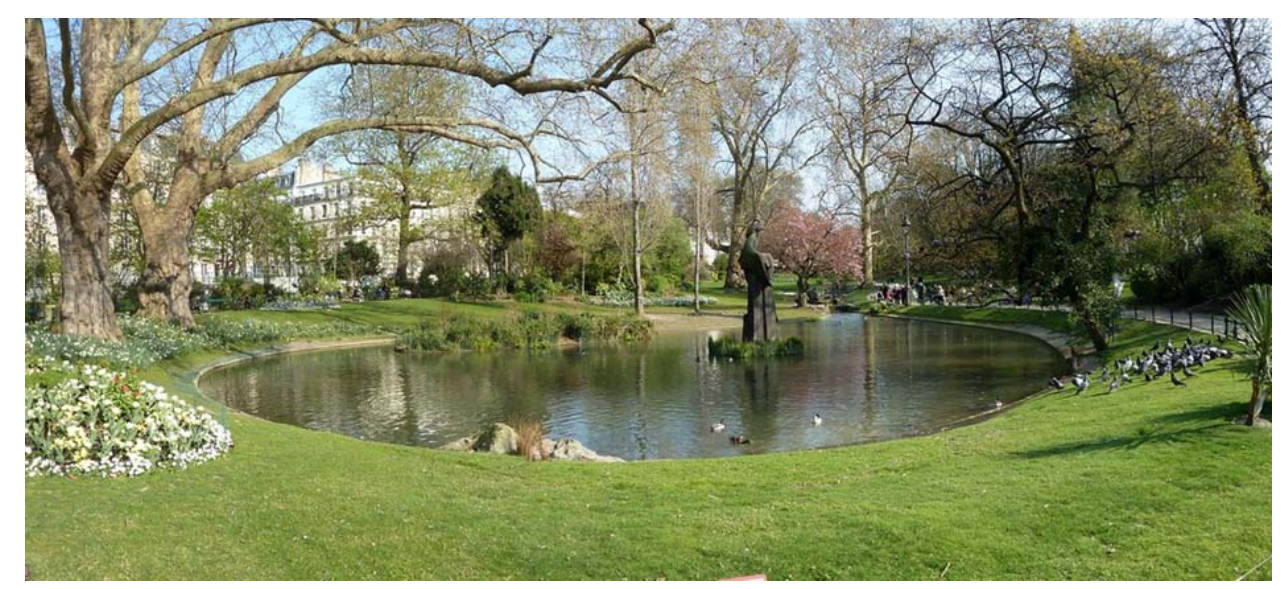

Figure 9. "Square” Batignolles (Paris - France), project by Jean-Charles Alphand (1879). Source: Fleg (2014).

\section{$20^{\text {th }}$ century}

Before the First World War (1914-1918), landscaping concepts emerged, with a modern language, with angular compositions and segmented plans and surfaces, with wide grassy areas (Walker and Simo, 1996). In 1914, Daniel Bellet and Will Darvillé launched the book Ce Que Doit être la Cité Moderne where they argue that "parks and large public gardens, the vast grounds for games and the spacious green squares are reservoirs of fresh air, and that the massive presence of vegetation and lawns becomes an indisputable element of calm and stillness" (Segawa, 1996).

\section{United States}

In the middle of the $17^{\text {th }}$ century, the USA began to receive immigrants from Northern Europe; who brought grass seeds and other herbs (Jenkins, 2015), which were considered very valuable. In 1672, twenty-two species of herbs had settled around Massachusetts Bay, including grasses (Bread et al., 2014). These grasses spread rapidly across the North American continent, such as the Guinea grass (Paspalum paniculatum) and the African grass (which became known as Bermuda grass) (Cynodon spp.) Which spread across the south; Kentucky bluegrass (Poa pratensis), originally from Europe and the Middle
East, which dispersed over the Appalachian Mountains and the Midwest; in the west, it was grasses originating in the Mediterranean, brought by Spanish soldiers and missionaries (Jenkins, 2015). In the early $19^{\text {th }}$ century, turfgrass was popular in the United States; parks in urban areas began to adopt the European model, with an emphasis on extensive lawns, and thus "green and lush turf" became the dominant feature of the "American way of life" (Jenkins, 2015).

Until the middle of the $19^{\text {th }}$ century, most houses in the United States were built without indentation, and had a small garden at the back of the house, with this design reflecting the emphasis on privacy attributed to the European residential. The transition to homes with gardens and lawns at the front was related to that advocated by Frederick Law Olmsted, that is, the presence of a public park with extensive green areas with turfgrass, and thus taking the lawns to the homes of ordinary Americans. Frederick Law Olmsted (1822-903) and Calvert Vaux (1824-1895) who designed today iconic public spaces, such as Central Park in New York/USA (Figures 10 and 11), as well as a new look in the residential space, in the suburb of Chicago, at Riverside, in 1869 (Figures 12 and 13), where it included a lawn for each home (Bread et al., 2014). 


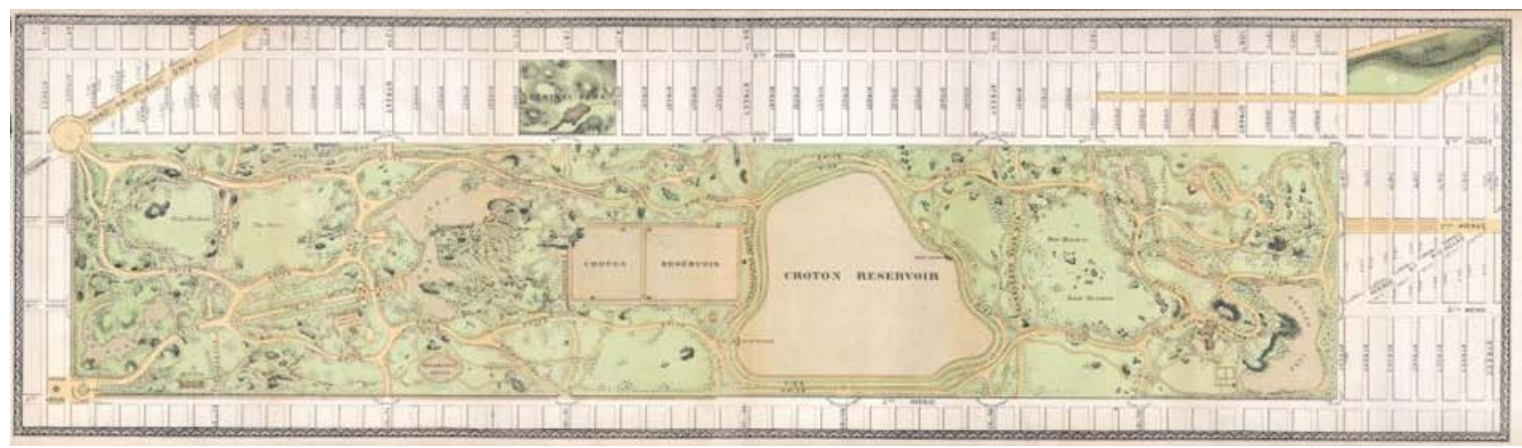

Figure 10. Central Park project (New York - USA) by Frederick Law Olmsted and Calvert Vaux (1869). Source: Explearth (2020).

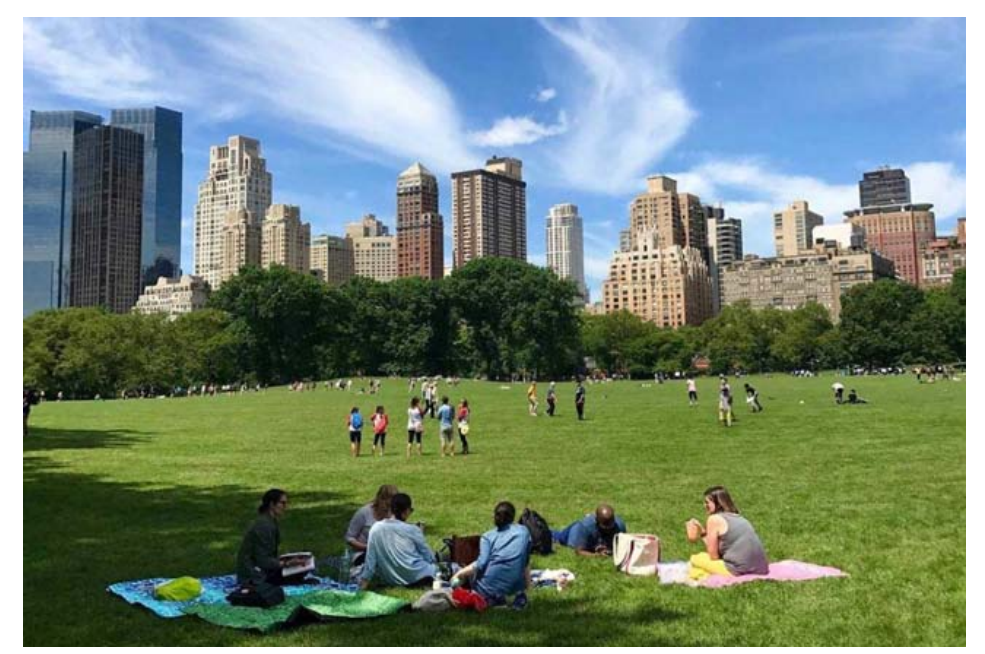

Figure 11. Appearance of the large Central Park lawn (New York - USA). Source: Angheben (2020).

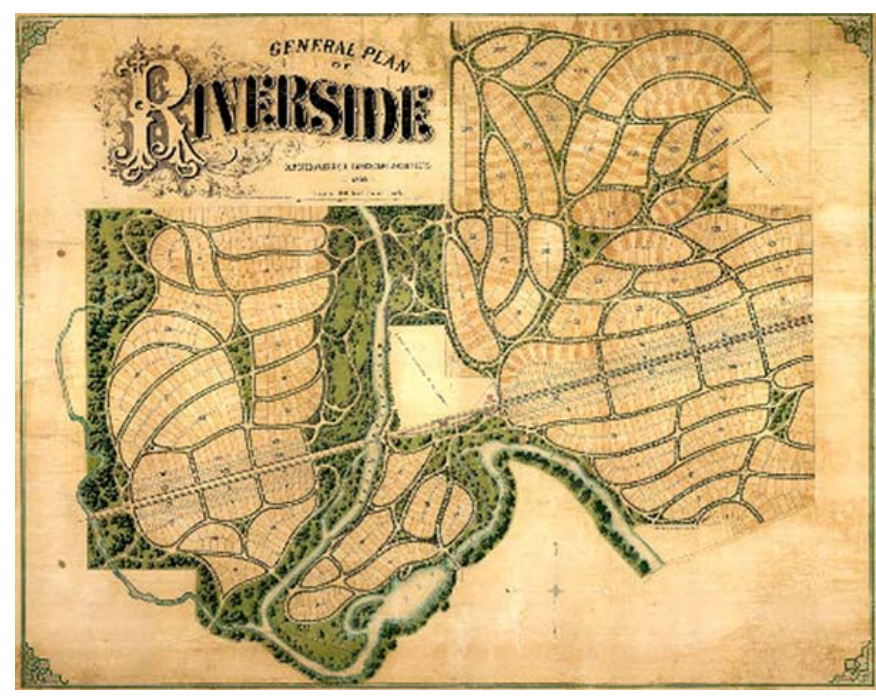

Figure 12. Project from 1869, by Frederick Law Olmsted and Calvert Vaux, for the suburb of Riverside, in Chicago/ Illinois - USA. Source: Barba (2012) 


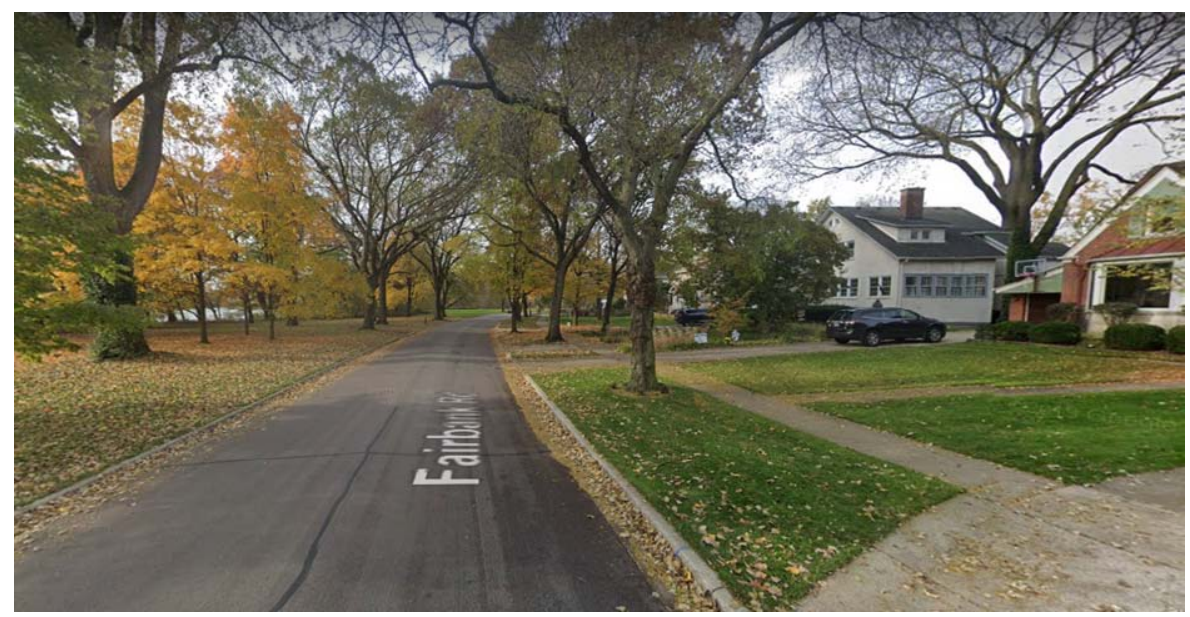

Figure 13. Fairbanks Street, Riverside, showing the integration between public and private space, through the use of lawns. Source: Google Street View (2019)

\section{The contemporary lawn}

In many parts of the world, the lawn is the most common of all resources in contemporary gardens, where it has played a significant role in the anthropogenic landscape (Smith and Fellowes, 2013). A more naturalistic approach to garden design began to emerge in the early $1990^{\text {s. }}$. Movements began in Europe, mainly in Germany, the Netherlands and also in the USA, arising from the growing concern about the need to reconnect with nature (Özgüner et al., 2017), leading to a widespread change in attitude towards the creation of the urban and residential outdoor space, as gardens bring quality to modern life. With the increasing awareness of the population regarding the need for more sustainable development, the landscaping project must be adapt, such as, for example, the use of rainwater collectors and the use of residual water (from domestic sewage) for irrigation of lawns (Alencar and Cardoso, 2015). Contemporary lawns are particularly valued as places for different outdoor activities such as playing, resting, having picnics, walking, socializing (Ignatieva et al., 2017), and are also used in extensive and intensive green roofs, parks and neighborhood green spaces. and zoos (Rall et al., 2015). Thus, a turfgrass is not just an individual object, but it carries the implicit message of being aesthetic, environmental and community (Hodgson, 2015). Among the contemporary urban green spaces, which have as main element extensive areas with lawn, there is the AndréCitröen Park (Alain Provost and Gilles Clément) in Paris/ France (Figure 14) and several landscape projects by Kim Wilkie (Orpheus at Boughton, in Northamptonshire/United Kingdom and Heveningham Hall, in Suffolk/England (Figure 15), among others (Richardson, 2000).

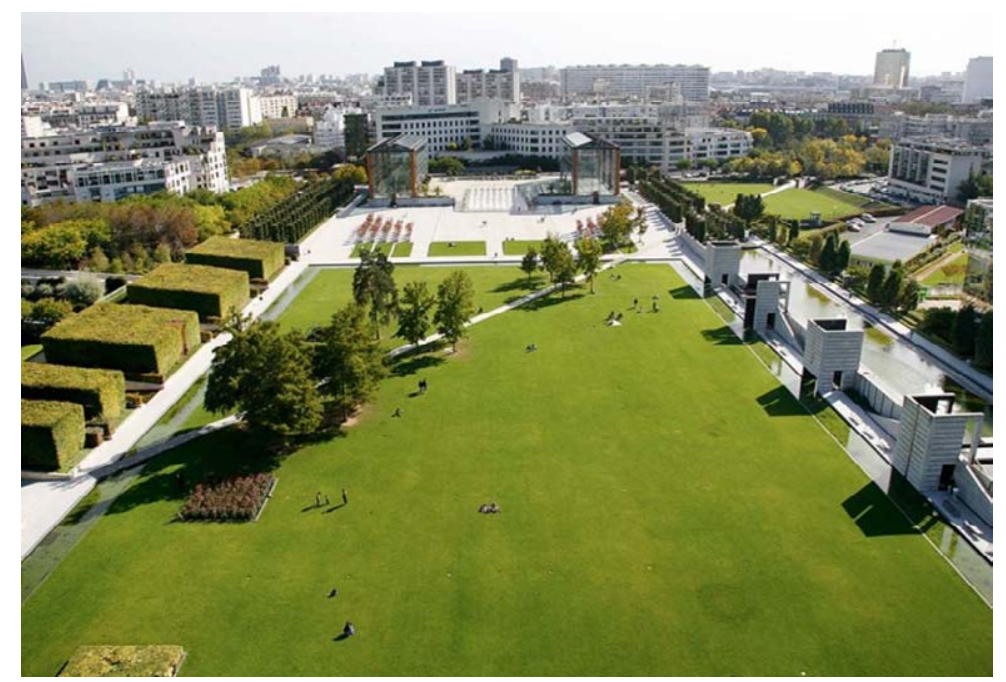

Figure 14. André-Citröen Park in Paris/France; project by Alain Provost and Gilles Clément. Source: Cool cities (2020) 


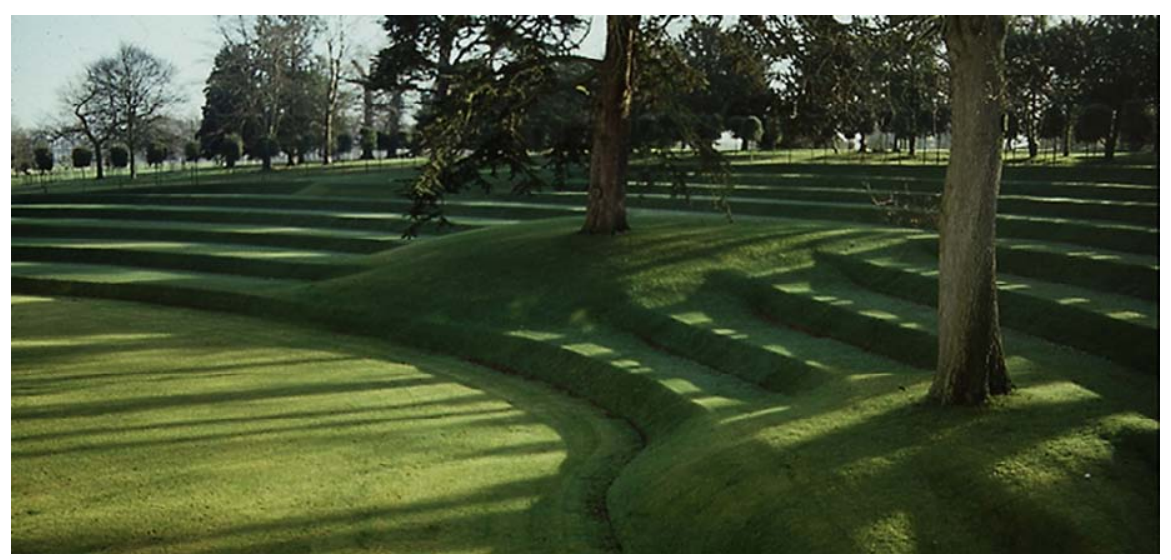

Figure 15. Heveningham Hall, Suffolk (England), designed by Kim Wilkie (1995). Source: Kim Wilkie (1995)

\section{The turf and turfgrass in Brazil}

As for the emergence of large lawns in Brazil, Segawa (1996) shows the presence of this vegetation in three situations, among others. In 1786, the English navigator John Barrow (1764-1848), then aged 22, visited Rio de Janeiro and described the Passeio Público (1779) as "an object of utility, in which the public's health and enjoyment was taken into account, being a garden to walk around; this land is laid out with bushes, lawns, boulevards and beds"
(Figure 16). The German Carl von Koseritz (1830-1890) reports in his impressions of the trip to Rio de Janeiro (1851), his greatest appreciation for the Passeio Público "the green surfaces of manicured and well-trimmed turfgrass pleased me extraordinarily and that was what really impressed me....". Manuel Duarte Moreira de Azevedo (1832-1903), in his first book on Rio de Janeiro (1862, revised and expanded in 1877), recorded, for the same garden, the thought of the time: “... different extension ..." (Figure 16).

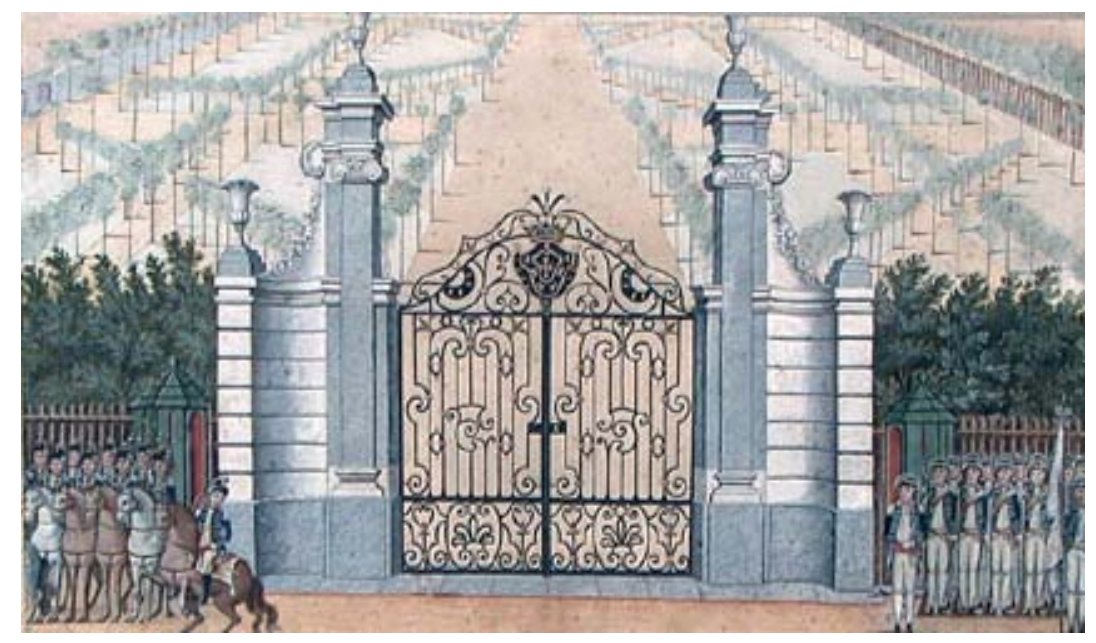

Figure 16. Entrance to the Passeio Público in Rio de Janeiro, in an anonymous painting from the end of the $18^{\text {th }}$ century. Source: Wikimedia Commons (2020). 


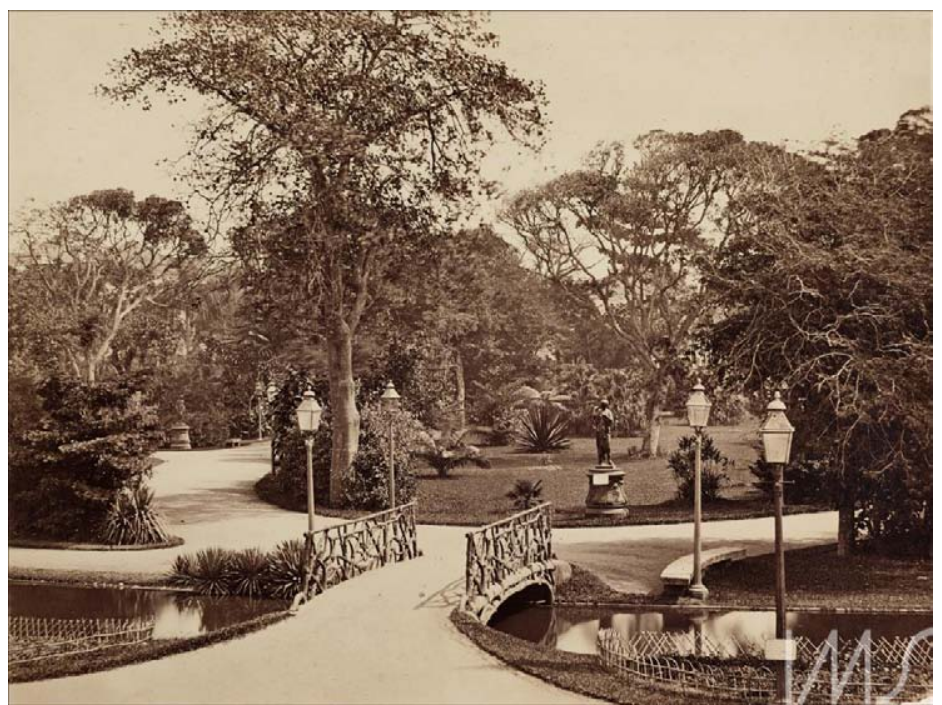

Figure 17. Passeio Público in Rio de Janeiro, photo by Augusto Stahl (1862). Source: Mestres do Séc. XIX (2020).

However, the use of grass in landscaping in Brazil had its great impetus with the arrival of Auguste François Marie Glaziou (1828-1906), in 1858, where it remained until 1893. He brought the concept tapis vert - French expression used to designate a large lawn. In the Jornal do Comércio, published on September 7, 1880, regarding the project in Campo de Santana (Rio de Janeiro, RJ) (Figure 18) it was stated that "The extensive lawns, from where from time to time some bushes stand out, produce magnificent effect" (Terra, 1993).

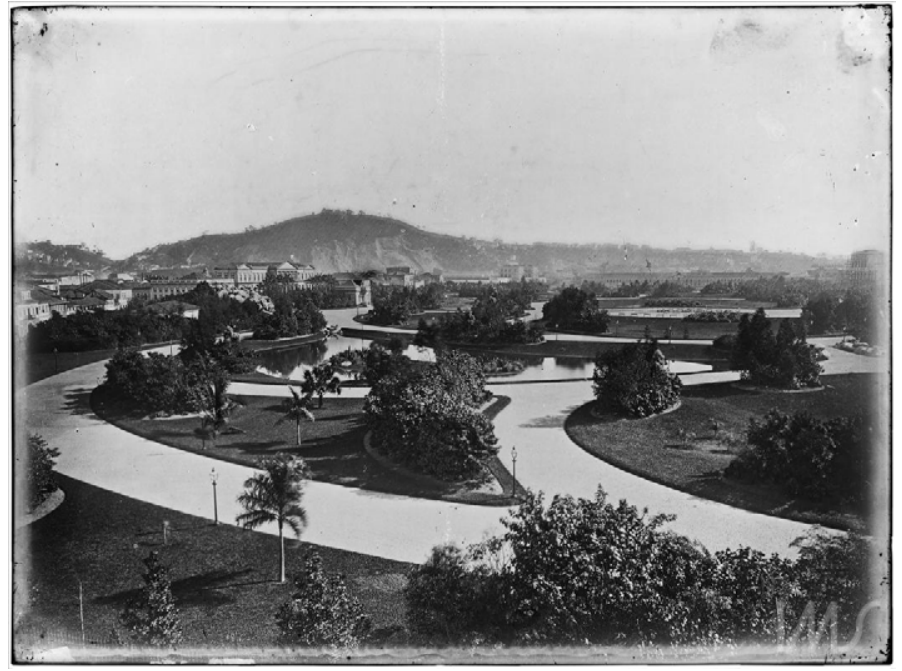

Figure 18. Campo de Santana (Rio de Janeiro/RJ; photo by Marc Ferrez (1880). Source: Coleção Gilberto Ferrez (2020).

In agreement with the aforementioned, Segawa (1996) comments that Émile Allain (1877-1951) spoke, in 1886, about the Campo da Aclamação: "During the winter, it is frequent that bad weather drives away sea gulls and that they come to the garden, where its almost white plumage contrasts sharply with the green of the lawn". In the $1920^{\mathrm{s}}$, according to Provenzano et al. (2018), the landscaping of Mina Klabin (1896 - 1969) appeared; in the residences of Rua Santa Cruz (1927) in Vila Mariana
(Figure 19) and Rua Itápolis (1930) in Pacaembú, both in the city of São Paulo-SP, she used extensive lawns and some species of tropical flora. Burle Marx (19091994) brings to the landscape, from 1935, according to the same author mentioned above, the character of the garden's exteriority, relating the public space and the surrounding environment, using wide turfgrass spaces in his projects, such as, for example: Gustavo Capanema Building (Rio de Janeiro-RJ), Generalissimo Francisco 
de Miranda Park (Caracas-Venezuela), Edmundo Canavelas House (Petrópolis-RJ), etc. Both in the Casa Edmundo Cavanelas (Figure 20), as in the currently called Parque Burle Marx (São Paulo-SP), the checkered lawn, composed of Emerald grass (Zoysia japonica) and St. Augustine grass (Stenotaphrum secundatum), is an important compositional element landscape and artistic design.

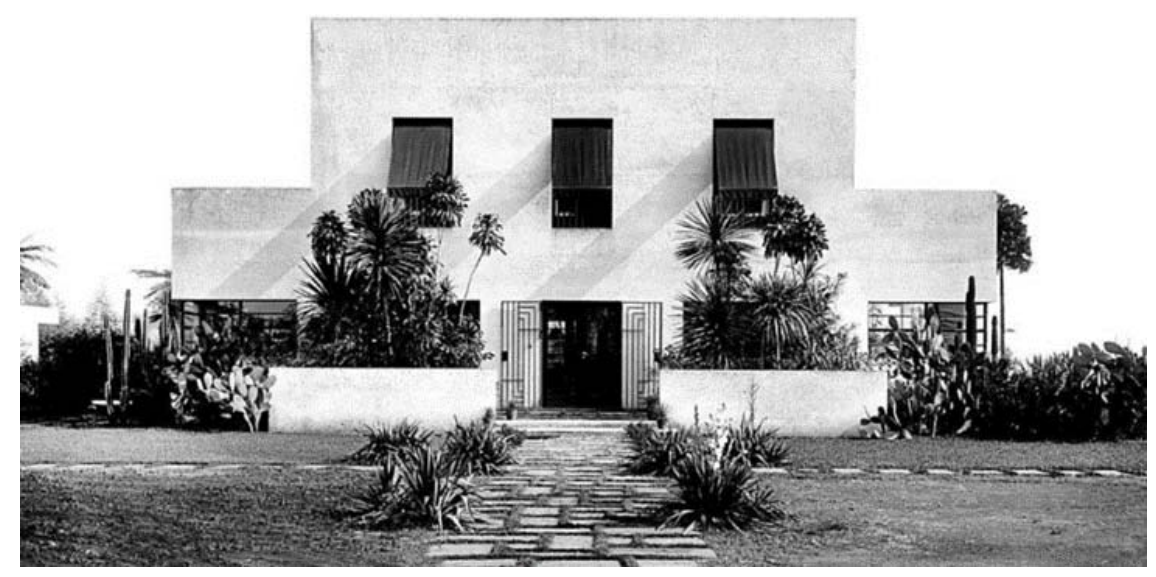

Figure 19. Casa da Rua Santa Cruz (1927), in Vila Mariana, São Paulo - SP; landscape design by Mina Klabin and architectural by Gregori Warchavchik. Source: Folha de São Paulo (2014)

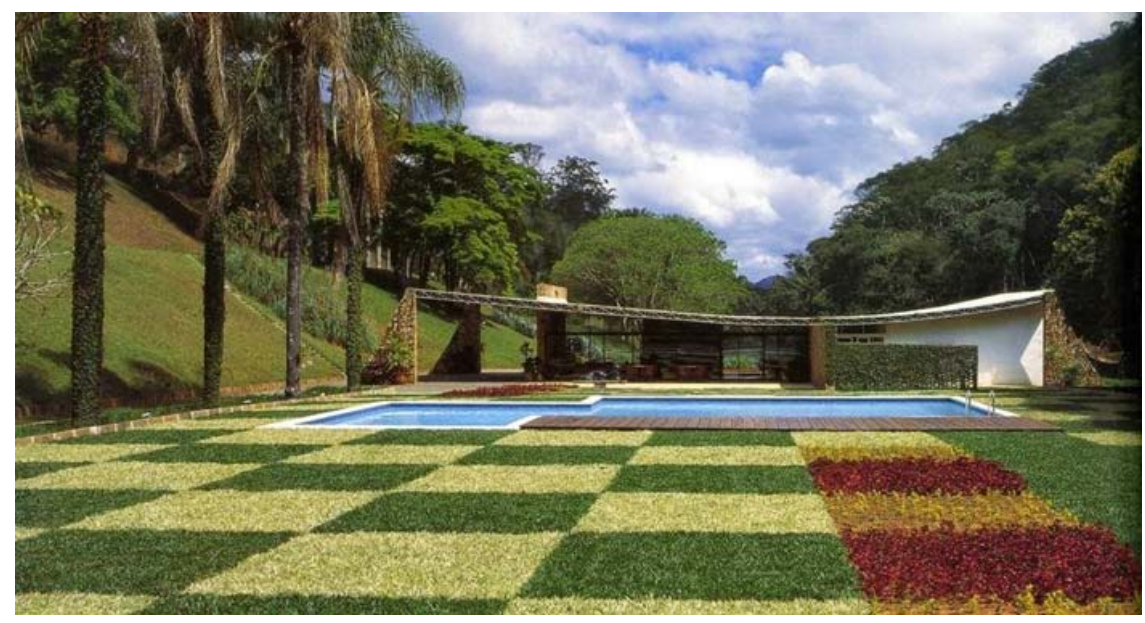

Figure 20. Checkered lawn, composed of Emerald grass (Zoysia japonica) and St Agostine grass (Stenotaphrum secundatum) at Casa Edmundo Cavanelas (1954), in Petrópolis - RJ; landscape design Burle Marx and architectural by Oscar Niemeyer. Source: Finotti (2018).

In 1960, the concept of "park cemetery" (or garden cemetery) appeared in Brazil, with extensive grassy areas and underground deposits identified by gravestones on the grass (Figure 21); it is necessary to meet specific technical requirements and conditions for such an undertaking (Pacheco, 2017). 


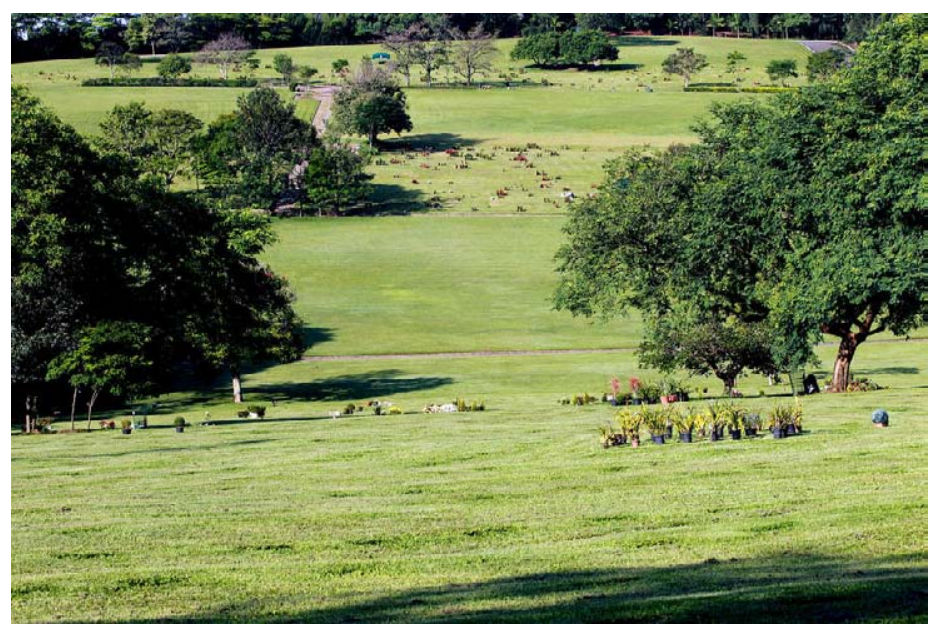

Figure 21. Parque do Morumbi Cemetery, in São Paulo - SP. Source: Estadão (2020)

Another use of lawns in contemporary landscaping is on green roofs (Santos et al., 2016; Ntoulas et al., 2017), which was already used by Burle Marx, in the Gustavo Capanema Building, opened in 1954. These are characterized as all coverage of the upper slab of buildings, for aesthetic purposes, improving environmental comfort, capturing and reusing water and preventing runoff, minimizing urban flooding (Santos and Castilho, 2018; Zhang et al. 2018). In Brazil, several municipalities have included public policies with reduced taxes for urban buildings that adopt this technology, such as Porto Alegre-RS (2007), Guarulhos-SP
(2011), Goiânia-GO (2012), Curitiba-PR (2015), SantosSP (2015) (Figure 22), Taubaté-SP (2016) and Mauá-SP (2017). Green roofs became mandatory only in the city of Recife, for residential buildings with more than four floors (RECIFE, 2015). In the city of São Paulo, since 2015, this system can be used as an option for environmental compensation (SÃO PAULO, 2015).

Currently in the Brazilian, 13 types of turfgrass have been using for different areas (Godoy et al., 2020), with specific purpose, mainly for landscaping, as shown in Table 1.

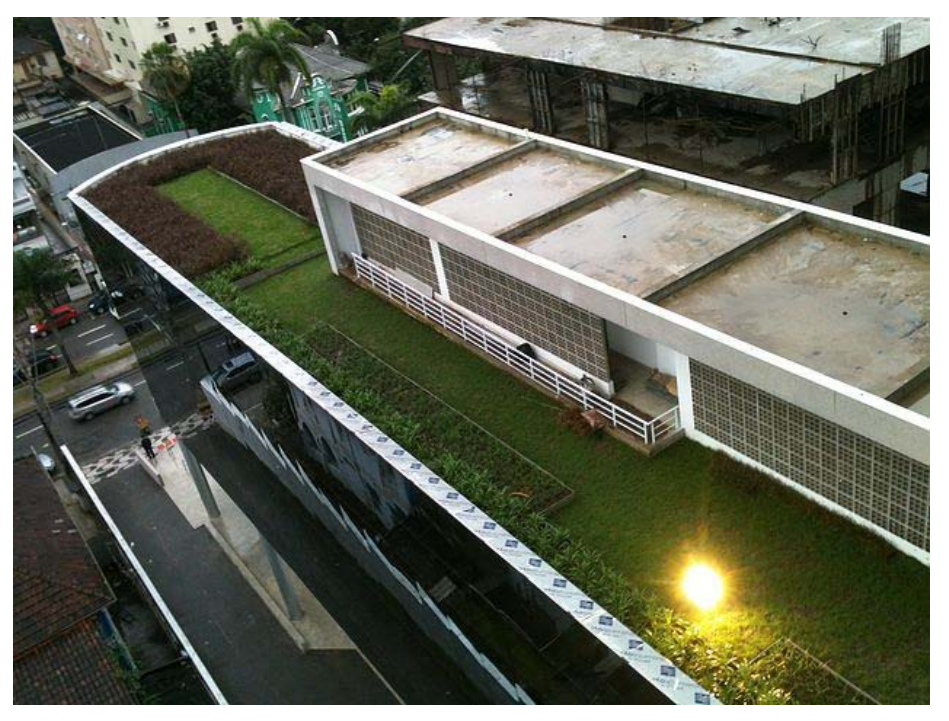

Figure 22. Green roof of the Ana Costa building, in Santos, SP. Source: NM Inovações (2020) 
Table 1. Main turfgrass species used in Brazilian landscaping.

\begin{tabular}{|c|c|c|}
\hline Common name & Species & Use \\
\hline Emerald grass & Zoysia japonica & $\begin{array}{l}\text { Public and private ornamental gardens, sports fields (golf, training centers for } \\
\text { athletic teams, low performance football), roadside. }\end{array}$ \\
\hline Bermuda grass & Cynodon spp. & $\begin{array}{l}\text { High performance sports fields; the variety ('Barazur') is suitable for } \\
\text { landscaping. }\end{array}$ \\
\hline Zeon grass & Zoysia matrella & Fairway areas of golf courses and ornamental gardens. \\
\hline Seashore & Paspaulum vaginatum & High performance sports fields *; it is tolerance to salinity. \\
\hline Geo Zoysia & $\begin{array}{l}\text { Zoysia japonica } \mathrm{x} \text { Zoysia } \\
\quad \text { tenuifolia }\end{array}$ & Residential lawns to extensive green areas. \\
\hline $\begin{array}{l}\text { St. Augustine } \\
\text { grass }\end{array}$ & Stenotaphrum secundatum & $\begin{array}{l}\text { Residential and business gardens in coastal regions, due to their tolerance to } \\
\text { salinity. }\end{array}$ \\
\hline Carpet grass & Axonopus spp. & $\begin{array}{c}\text { Residential lawns, extensive green areas (parks and industries) and semi-shaded } \\
\text { locations. }\end{array}$ \\
\hline Bahia grass & Paspalum notatum & $\begin{array}{c}\text { Margins of highways, residential gardens, squares, parks and low performance } \\
\text { sports fields. }\end{array}$ \\
\hline
\end{tabular}

* the 'Platinum' variety is used in the Qatar 2022 world cup fields.

Among the species in Table 1, the Carpet grass, Seashore and Bahia grass are native to Brazil (Godoy et al., 2012; Souza et al., 2020a). However, the majority of lawns formed by Bahia grass result from planting by "pieces" collected manually in degraded pasture areas (Souza et al., 2020a). Thus, "Embrapa Pecuária Sudeste" (São Carlos, SP) started to conduct research for the production and commercialization of Paspaslum and Axonopus spp. (Souza et al., 2020b) that were recently registered with the Ministry of Agriculture.

\section{Conclusions}

Nowadays, great Brazilian landscapers, depending on the style (or mix of styles) make use of extensive grassy areas, given the sense of freedom and tranquility that they bring, making the areas for leisure, recreation or contemplation functional. Citing Cânovas (2015): "the gardens, no matter how small, become more friendly when an area is occupied by a natural carpet, the reason is simple. It is the main responsible in the perspective of the landscaping, and in the depth of the other elements that form the green area, so much so that the English revolutionized the landscape architecture, using the grasses to accentuate the relief of the terrain, thus increasing, the feeling of space and giving a definitive contribution to the garden designer". Finally, it is always worth remembering that in the Letter of Athens/Athens (1933), signed by Le Corbusier and other urban planners. He says that cities must give to the citizen, "in sufficient proportions, elements indispensable to living beings: sun, space and vegetation, fundamental issues both psychological and physiological" (International Congress of Modern Architecture, 1933) (Corbusier, 1993).

\section{Author Contribution}

RMMC: Critical review, bibliographic search, interpretation and structuring of the text, approval of the final version. RCF: Critical review, bibliographic search, interpretation and structuring of the text. PLFS: Critical review, bibliographic search, interpretation and structuring of the text and translation.

\section{Acknowledgements}

VerdeCidade (Sabadão) - Study, Research and Extension Group at Unesp/Ilha Solteira Campus.

In memory Victor Augusto Stek, passionate about lawns and life.

\section{References}

ALBERTUS MAGNUS. De vegetabilis et plantis libri septem. Available at: $<$ http://albertusmagnus.uwaterloo.ca/ PDFs/De\%20vegetabilibus-Meyer-Jessen.pdf $>$. Accessed on July $24^{\text {th }}, 2020$.

ALENCAR, L.D.; CARDOSO, J.C. Paisagismo funcional - o uso de projetos que integram mais que ornamentação. Revista Ciência, Tecnologia \& Ambiente, v.1, n.1, p.1-7, 2015.

ANGHEBEN, F. Atrações no central park: 20 lugares para conhecer. Available at: <https://dicasnovayork.com.br/20atracoes-no-central-park/>. Accessed on July 24 $4^{\text {th }}, 2020$.

ARTS AND CULTURE. The Large piece of turf, 1503. Available at: $<$ https://artsandculture.google.com/asset/thelarge-piece-of-turf-1503/NgELdACk3I8Jkg $>$. Accessed on July $24^{\text {th }}, 2020$. 
BARBA, F.G. Riverside construção suburban. 2012. Available at: $<$ https://arquiscopio.com/archivo/2012/06/03/ urbanizacion-suburbana-de-riverside/?lang $=\mathrm{pt}>$. Accessed on: July $24^{\text {th }}, 2020$.

BEARD, J.B.; BEARD, H.J.; BEARD, J.C. Turfgrass history and literature: lawns, sports and golf. East Lansing: Michigan State University Press, 2014. 544p.

BEARD, J.B.; GREEN, R.L. The role of turfgrasses in environmental protection and their benefits to humans. Journal of Environmental Quality, v.23, n.3, p.452-460, 1994.

BOUCHENAK-KHELLADI， Y.; VERBOOM G.A.; SAVOLAINEN, V.; HODKINSON, T.R. Biogeography of the grasses (Poaceae): a phylogenetic approach to reveal evolutionary history in geographical space and geological time. Botanical Journal of the Linnean Society, v.162, n.4, p.543-557, 2010. DOI: https://doi.org/10.2134/ jeq1994.00472425002300030007x

BOVO, M.C.; AMORIM, M.C.C.T. Análise dos aspectos paisagísticos e de infraestrutura de áreas verdes urbanas: o caso de algumas praças de Maringá (PR) Brasil. Revista de Geografia, Meio Ambiente e Ensino, v.2, n.1, p.83-95, 2012.

CÂNOVAS, R. O gramado no paisagismo suas histórias. In: VILLAS BÔAS, R.L.; GODOY, L.J.G. SIGRA: Atualidades e Perspectivas, Botucatu: GEMFER, 2006. p.39-42.

COLEÇÃO GILBERTO FERREZ. Campo de Santana. Available at: < http://brasilianafotografica.bn.br/brasiliana/ handle/20.500.12156.1/6774>. Accessed on: July $24^{\text {th }}, 2020$.

COOL CITIES. Parc André Citroën. Available at: $<$ https://www.cool-cities.com/parc-andre-citroen-1150/>. Accessed on: July $24^{\text {th }}, 2020$.

CORBUSIER, L. Carta de Atenas. São Paulo: Edusp. 1933. 146p.

CURITIBA (Município). Lei no 14.771 de 17 de dezembro de 2015. Dispõe sobre a revisão do plano diretor de Curitiba de acordo com o disposto no art. $40, \S 3^{\circ}$, do estatuto da cidade, para orientação e controle do desenvolvimento integrado do município. Diário Oficial [do] Município Curitiba, Curitiba, PR, n.236, 17 dez. 2015. Available at: http://leismunicipa.is/pmhqu. Accessed on: December $28^{\text {th }}$, 2017.

EAST, J.W. An Edwardian Architect in Brisbane: The work of Claude William Chambers, 1889-1914. Queensland: University of Queensland Library Staff Publications and Presentations, 2020. 125p.

ESTADÃO. Túmulos de celebridades atraem visitas ao cemitério do Morumby 12/18/2014. Available at: $<$ https://fotos.estadao.com.br/galerias/cidades,tumulosde-celebridades-atraem-visitas-ao-cemiterio-domorumby,13737>. Accessed on: July $24^{\text {th }}, 2020$.
EXPLEARTH. Genius of place: the national parks, olmsted \& landscape urbanism. Available at: https:// explearth.org/genius-of-place-national-parks-olmsted/. Accessed on: July 24 ${ }^{\text {th }}, 2020$.

FINOTTI, L. O natural e o construído. 2018. Available at: <https://www.vitruvius.com.br/revistas/read/projetos/ 18.214/7139>. Accessed on: July $24^{\text {th }}, 2020$.

FLEG, D. Square des Batignolles. 2014. Available at: $\quad<$ https://www.flickr.com/photos/96315238@ N02/13611508185>. Accessed on: July $24^{\text {th }}, 2020$.

FOLHA DE SÃO PAULO. Gregori Warchavchik: Veja construções do arquiteto Gregori Warchavchik. 2014. Available at: <https://fotografia.folha.uol.com.br/ galerias/23225-gregori-warchavchik $>$. Accessed on: July $24^{\text {th }}, 2020$.

FRAME POOL. Royal Botanic Gardens, Reino Unido 2000. Available at: <http://footage.framepool.com/zh/ shot/810629975-kew-gardens-botanical-garden-pagodapark $>$. Accessed on July $24^{\text {th }}, 2020$.

GARDENS BEFORE. Primeiros Jardins europeus. 2018. $<$ https://gardensbefore1800.blogspot.com/2018/01/1600florence-villa-gardens-villa-di.html $>$. Accessed on: July $24^{\text {th }}, 2020$.

GODOY, L.J. Turfs and turfgrasses in Brazil. Ornamental Horticulture, v.26, n.3, 2020 p.326-327, 2020. DOI: https://doi.org/10.1590/2447-536X.v26i3.2224

GODOY, L.J.G.; VILLAS BÔAS, R.L.; BACKES, C.; SANTOS, A.J.M. Nutrição, Adubação e Calagem para produção de gramas. Botucatu: FEPAF, 2012. 146p.

GOIÂNIA (Município). Lei complementar no 235, de 28 de dezembro de 2012. Institui o PROGRAMA IPTU VERDE no Município de Goiânia. Diário Oficial [do] Município Goiânia, Goiânia, GO, 28 de dezembro de 2012. Available at: <http://www.goiania.go.gov.br/html/gabinete_civil/ sileg/dados/legis/2012/lc_20121228_000000235.pdf $>$. Accessed on: December 28 ${ }^{\text {th }}, 2017$.

GOOGLE STREET VIEW. Rua Fairbanks, Riverside, Illinois 2020. Available at: <https://www.google.com.br/ maps/@41.8205212,-87.8251328,3a,75y,228.23h,86.23t/ data $=$ !3m6! $1 \mathrm{e} 1 ! 3 \mathrm{~m} 4$ ! 1 seJeOI0ON2d7ypBUtZuXVeA!2e0 !7i16384!8i8192>. Accessed on: July 24 $4^{\text {th }}, 2020$.

HABER, W. Landscape ecology as a bridge from ecosystems to human ecology. Ecological Research, v.19, n.1, p. 99-106, 2004. DOI: https://doi.org/10.1111/j.14401703.2003.00615.x 
HEJCMAN, M.; HEJCMANOVÁ, P.; PAVLŮ, V.; BENEŠ, J. Origin and history of grasslands in Central Europe - a review. Grass and Forage Science, v.68, n.3, p.345-363, 2013. DOI: https://doi.org/10.1111/gfs.12066

HODGSON, I. Great garden design: contemporary inspiration for outdoor spaces. London: Frances Lincoln, 2015. 176p.

HOLZER, W. Paisagem, imaginário, identidade: alternativas para o estudo geográfico. Manifestações da cultura no espaço. Rio de Janeiro: EdUERJ, p.149-168, 1999.

ICONOGRAPHIE CHRÉTIENNE. Saint Abert le grand (Albertus Magnus), religieux dominicain, évêque et Docteur de l>Église. 2012. Available at: $<$ http://har22201. blogspot.com/2012/11/saint-albert-le-grand.html>. Accessed on: July, 24, 2020.

IGNATIEVA, M.; ERIKSSON, F.; ERIKSSON, T.; BERG, P.; HEDBLOM, M. The lawn as a social and cultural phenomenon in Sweden. Urban Forestry \& Urban Greening, v.21, p.213-223, 2017. DOI: https://doi. org/10.1016/j.ufug.2016.12.006

IGNATIEVA, M.; HAASE, D.; HUSHKOVA, D.; HAASE, A. Lawns in cities: from a globalised urban green space phenomenon to sustainable nature-based solutions. Land, v.9, n.3, p.73, 2020. DOI: https://doi.org/10.3390/land9030073

JENKINS, V. The lawn: A history of an American obsession. Washington: Smithsonian Institution, 2015. 246p.

KELLOGG, E.A. Evolutionary history of the grasses. Plant physiology, v.125, n.3, p.1198-1205, 2001. DOI: https://doi.org/10.1104/pp.125.3.1198

KIM WILKIE. Heveningham Hall Suffolk, for a private client. 1995. Available at: <https://www.kimwilkie.com/ uk/heveningham-hall/>. Accessed on July 24 ${ }^{\text {th }}, 2020$.

KOPEC, D. The History of the "Lawn" and turfgrass development. Tucson: Cooperative Extension, 2015. 2p.

LINGLUNG. Tópico William Kent, designer de jardins paisagísticos. 2016. Available at: <http://linglung7. blogspot.com/2016/10/topic-william-kent-landscapegarden.html>. Accessed on: July $24^{\text {th }}, 2020$.

LIU, Y. Seeds of a different Eden: Chinese Gardening ideas and a New English aesthetic ideal. Columbia: University of South Carolina Press, 2008. 208p.

MAUÁ (Município). Lei $\mathrm{n}^{\circ} 5199$, de 10 de janeiro de 2017. Institui o Programa de Incentivo e Desconto, denominado "IPTU Verde", no Município de Mauá, e dá outras providências. Diário Oficial [do] Município Mauá. Available at: <http://dom.maua.sp.gov.br/ LegislacaoNumero.aspx $>$. Accessed on July $24^{\text {th }}, 2020$.
MESTRES DO SÉC. XIX. Passeio Público 1862. Available at: $\quad<$ http://brasilianafotografica.bn.br/brasiliana/handle/ 20.500.12156.1/2039>. Accessed on: July $24^{\text {th }}, 2020$.

NEVES, L.A.S. Da Antiguidade à redescoberta das leis de Mendel. Santa Maria: Editora UFSM, 2006. 274p.

NM INOVAÇÕES. 'Telhado verde' começa a ganhar espaço em santos e abate o IPTU. 2020. Available at: $<$ https://www. vitruvius.com.br/revistas/read/projetos/18.214/7139>. Accessed on: July, 24, 2020.

NTOULAS; N.; NEKTARIOS, P.A.; KOTOPOULIS, G.; ILIA, P.; TTOOULOU, T. Quality assessment of three warm-season turfgrasses growing in different substrate depths on shallow green roof systems. Urban Forestry \& Urban Greening, v.26, p.163-168. DOI: https://doi. org/10.1016/j.ufug.2017.03.005

OLIN, L. The Long Shadow of André Le Nôtre. SiteLINES: A Journal of Place, v.12, n.2, p.3-6, 2017.

ÖZGÜNER, H.; KENDLE, A.D.; BISGROVE, R.J. Attitudes of landscape professionals towards naturalistic versus formal urban landscapes in the UK. Landscape and Urban Planning, v.81, n.1-2, p.34-45, 2007. DOI: https:// doi.org/10.1016/j.landurbplan.2006.10.002

PACHECO, A. Meio ambiente \& cemitérios. São Paulo: Senac, 2017. 190p.

PAIVA, P.D. Paisagismo: conceitos e aplicações. Lavras: Editora UFLA, 2008. 604p.

PEDAÇOS DE NÓS. O castelo de Guimarães. 2017. Available at: <http://pedacosdenos.com/2017/02/13/ castelo-de-guimaraes/>. Accessed on: July 24th, 2020.

PIKABU. Castelo antigo na Irlanda. 2018. Available at: $<$ https://pikabu.ru/story/irlandiya_6074168>. Accessed on: July $24^{\text {th }}, 2020$.

POINAR, G.J.; ALDERMAN, S.; WUNDERLICH, J. One hundred million year old ergot: psychotropic compounds in the Cretaceous. Palaeodiversity, v.8, p.13-19, 2015.

PORTO ALEGRE (Município). Instrução no 22, de 11 de outubro de 2007. Visa garantir nos imóveis, Área Livre de qualquer intervenção, permeável, passível de arborização e dá outras providências. Diário Oficial [do] Município Porto Alegre, Porto Alegre, RS, n 3169, 12 dez. 2007. Available at: Accessed: <http://lproweb.procempa.com.

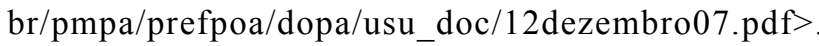
Accessed on December $28^{\text {th }}, 2017$.

PRASAD, V.;STROEMBERG,C.A.E.;ALIMOHAMMADIAN, H.; SAHNI, A. Dinosaur coprolites and the early evolution of grasses and grazers. Science, v.310 n.5751 p.1177-1180, 2005. DOI: DOI: https://doi.org/10.1126/science.1118806 
PROVENZANO, T.L.; SOUZA, J.P.; TISSOT, J.T. A contribuição do estudo de caso para o processo de projeto: uma experiência de ensino de projeto paisagístico. Revista Projetar-Projeto e Percepção do Ambiente, v.3, n.3, p.61-70, 2018.

RALL, L.; NIEMELA, J.; PAULEIT, S.; PINTAR, M.; LAFORTALEZZA, R; SANTOS, A.; ŽELEZNIKAR Š. A typology of urban green spaces, eco-system services provisioning services and demands. Report D3, v.1, 2015.

RECIFE. Lei Municipal $\mathbf{n}^{0} \mathbf{1 8 . 1 1 2}$ de 2015. Dispõe sobre a melhoria da qualidade ambiental das edificações por meio da obrigatoriedade de instalação do "telhado verde", e construção de reservatórios de acúmulo ou de retardo do escoamento das águas pluviais para a rede de drenagem e dá outras providências. 2015. Available at: <https:// ecotelhado.com/wp-content/uploads/2015/03/Lei-telhadoverde-Recife-2015.pdf $>$. Accessed on December $28^{\text {th }}$, 2017.

RICHARDSON, T. The garden book. London: Phaidon, 2000. 512p.

SANTOS, P.L.F.; BARCELOS, J.P.Q.; CASTILHO, R.M.M. Diferentes substratos no desenvolvimento de um gramado ornamental para uso em telhados verdes. Periódico Técnico e Científico Cidades Verdes, v.4, n.10, p.81-94, 2016. DOI: http://dx.doi.org/10.17271/23178604 41020161393

SANTOS, P.L.F.; CASTILHO, R.M.M. Floriferous herbaceous and substrates for use on extensive green roofs, Ornamental Horticulture, v.24, n.3, p.261-268, 2018. DOI: https://doi.org/10.14295/oh.v24i3.1251

SANTOS. Projeto aprovado incentiva o Telhado Verde. 2015. Available at: <https://www.camarasantos.sp.gov. br/publico/noticia.php?codigo $=6240>$. Accessed on July 24th, 2020.

SÃO PAULO (Município). Decreto $\mathbf{n}^{0}$ 55.994, de 10 de março de 2015. Introduz alterações no artigo $4^{\circ}$ do decreto $\mathrm{n}^{\mathrm{o}} 53.889$, de 8 de maio de 2013, que regulamenta o termo de compromisso ambiental - TCA. 2015. Available at: $\quad<$ https://leismunicipais.com.br/a/sp/s/sao-paulo/ decreto/2015/5599/55994/decreto-n-55994-2015-introduzalteracoes-no-artigo-4-do-decreto-n-53889-de-8-de-maiode-2013-que-regulamenta-o-termo-de-compromissoambiental-tca.html $>$. Accessed on: December 28 ${ }^{\text {th }}, 2017$.

SEGAWA, H.M. Ao amor do público: jardins no Brasil. São Paulo: Fapesp, Studio Nobel, 1996. 256p.
SHIPLEY, G.P.; KINDSCHER, K. Evidence for the Paleoethnobotany of the Neanderthal: A Review of the Literature. Scientifica, v.2016, p.1-12, 2016. DOI: https:// doi.org/10.1155/2016/8927654

SMITH, L.S.; FELLOWES, M.D.E. Towards a lawn without grass: the journey of the imperfect lawn and its analogues. Studies in the History of Gardens \& Designed Landscapes, v.33, n.3, p.157-169, 2013. DOI https://doi.or $\mathrm{g} / 10.1080 / 14601176.2013 .799314$

SOUZA, F.H.D.; CAVALLARI, M.M.; GUSMÃO, M.R. Produção comercial de sementes de Paspalum notatum var. notatum. São Carlos: Embrapa Pecuária Sudeste, 2020a. 22p.

SOUZA, F.H.D.; GUSMÃO, M.R.; CAVALLARI, M.M.; BARIONI JÚNIOR, W.B. Characterization of the potential of native grasses for use as lawns. Ornamental Horticulture, v.26, n.1, p.109-120, 2020b. DOI: https:// doi.org/10.1590/2447-536x.v26i1.2067

STEWART, J.W. Parks and Gardens in Greater Paris. Fellbach: Axel Menges, 2012. 192p.

TAKEI, J.; KEANE, M.P. Sakuteiki: Visions of the Japanese garden. North Clarendon: Tuttle Publishing, 2011. 256p.

TAUBATÉ (Município). Lei no 5241, de 30 de dezembro de 2016. Institui o Programa IPTU Verde no Município de Taubaté, e dá outras providências. Diário Oficial [do] Município Taubaté, Taubaté, SP, 30 de dezembro de 2016. Available at: <https://leismunicipais.com.br/a/sp/t/taubate/ lei-ordinaria/2016/525/5241/lei-ordinaria-n-5241-2016institui-o-programa-iptu-verde-no-municipio-de-taubatee-da-outras-providencias $>$. Accessed on December $28^{\text {th }}$, 2017.

TERRA, C.G. Os jardins no Brasil no século XIX: Glaziou revisitado. 2ed. Rio de Janeiro: EBA/UFRJ, 2000. 272p.

TOMASI, L.T.; HIRSCHAUER, G.A. The flowering of Florence: botanical art for the Medici. Exhibition catalog. Washington: National Gallery of Art, 2002. 132p.

UNGAR, P.S.; SPONHEIMER, M. Hominin diets. A companion to paleoanthropology. New York: WileyBlackwell, 2013. p.165-182.

URMY, C. Watching grass grow: a history. Studies in the History of Gardens \& Designed Landscapes, v.40, n.1, p.1-13, 2020. DOI: https://doi.org/10.1080/14601176.201 9.1600833 
WALKER, P.; SIMO, M.L. Invisible gardens: the search for modernism in the American landscape. Cambridge: MIT Press, 1996. 382p.

WIKIMEDIA COMMONS. Inauguration of the Passeio Público (Public Park) in Rio de Janeiro, Brazil 1779. Available at: <https://commons.wikimedia.org/wiki/ File:InauguracaoPortaoPasseio-finsXVIII-anonimo.jpg>. Accessed on: July 24th, 2020.
YANG, F.; IGNATIEVA, M. LARSON, A. XIU, N.; ZHANG, S. Historical Development and Practices of Lawns in China. Environment and History, v.25, n.1, p.23-54, 2019. DOI: $10.3197 / 096734018 X 151379495920$ 98 